\title{
INSTILLING SPIRIT OF NATIONALISM AND PATRIOTISM IN YOUNG GENERATION IN THE MIDDLE OF PLURALISM
}

\author{
M. Guntoro \\ 17 August 1945 University of Cirebon, Jawa Barat 45131, Indonesia
}

\begin{abstract}
The issue that currently developing is many young Indonesians do not understand their role as the nation's children. The impact on the nation and state is the Indonesian nation will lose the nation's successive generation (the lost generation). This issue must be addressed as a national issue in which the right solution must be sought. The solution that must be done immediately is to instill the values of nationalism and patriotism in the younger generation so that they avoid deviant and negative behavior. The purpose of this research is to describe the condition and instill the spirit of nationalism and patriotism in the young generation amidst pluralism. This research method is carried out by describing the conditions that occur in Indonesia, then the discussion is carried out using qualitative methods, where the source of information obtained from this research is based on literature studies from various sources. The values of universal let cultivated for generations of young people in a pluralistic society. To socialize these universal values, the role of educational institutions is needed. Institute of education has the advantage in the form of human self or group in a plural society. The crisis of authority, modeling, kepanutan, and beliefs strongly influence the socialization of educational institutions power in order to dampen the vulnerability of conflict in pluralistic society.
\end{abstract}

Key words: Nationalism, Patriotism, Pluralism.

Cite this Article: M. Guntoro, Instilling Spirit of Nationalism and Patriotism in Young Generation in the Middle of Pluralism, International Journal of Management (IJM), 11(12), 2020, pp. 3307-3313. http://iaeme.com/Home/issue/IJM?Volume $=11 \&$ Issue $=12$

\section{INTRODUCTION}

The issue currently developing is many young Indonesians do not understand their role as the nation's children. Although since every level of formal education, the students have studied the eyes of the lessons of history and Pancasila education/citizenship, and has also been frequently commemorate the great national such as: the awakening of national, the hero, the Independence Day, the birthday of the military, and so on, but a lot of the younger generation who do not 
understand and understand about nationalism and patriotism. In addition, many are also young people who spoil themselves with negatives activities like: there are still many students who skip during school, many who do not love the product in the country, dirty gravities everywhere are destroying the beauty of the environment, there are those who do not obey the rules school, take out the trash

carelessly, fights between students, drug abuse, brawls, motorcycle gangs, free sex, and so on. This behavior is not only detrimental to himself but also detrimental to the community around him. The impact to the nation and the nation state, Indonesia will lose successive generation to the nation (the lost generation). This issue must be addressed as a national issue in which the right solution must be sought. The solution immediately should do is reassert the values of nationalism and patriotism in young generation so they avoid aberrant behavior and negative.

Based on the above, the purpose of this study is to describe the conditions and instill the spirit of nationalism and patriotism in pluralism young generation.

\section{METHOD}

This research was conducted by describing the conditions that occurred in Indonesia, then the discussion was carried out using qualitative methods, where the source of information obtained from this study is based on literature studies from various sources.

\section{DISCUSSION}

\subsection{Nationalism and Patriotism}

Theoretically, nationalism is an understanding (teaching) to love the nation and the country itself. Awareness of membership in a nation together potentially or actually to achieve, maintain and devote national identity, integrity, prosperity and strength, namely the spirit of nationality. Meanwhile, patriotism is a brave, unyielding and willing to sacrifice for the nation and state. Patriotism comes from the words "patriot" and "ism" which means heroism or heroic spirit. The sacrifice can material and physical assets. Thus, patriotism can be interpreted as a selfsacrificing attitude to defend the nation and state from domestic and external disturbances.

The two attitudes are interrelated or related, meaning that if someone already has a sense of nationalism he will automatically have a sense of patriotism. The problem is, how to instill these two values in today's younger generation. Maybe this is homework for all elements of society, including parents, teachers, lecturers, and policy makers/ government.

Nationalism and patriotism at this time no longer must come up arms and defend the State, but can be realized in the form of the other, such as how the name of nation to excel in the field of sports, arts, culture, mastery of science, and so on. Special to the student, let student who has the academic achievement and has achievements in activities on campus. This means student must have moral and intellectual intelligence and also have skills and wisdom in behaving and acting, so student as agents of change, social of control and moral force are not just slogans.

Nationalism is a "filter" that will be able to filter out any intervention from any party, which wants to undermine the sacred values this nation has. Before the components of the nation, including the younger generation, must remain committed and consistent in strengthening the spirit of nationalism supported by idealism and patriotism, for the sake of the glory and prosperity of the Indonesian nation now and in the future.

\subsection{The Concept of Plurality}

Plural society is prone to conflict. Indonesian society is a pluralistic society, and as a plural society, Indonesian society is also prone to conflict. In its history, Indonesia also has 
experienced various kinds of conflicts, both racial and non- racial, such as conflicts between ethnic, religion, politics, economics, and others. This condition cannot be allowed to continue. Conflict cannot be eliminated completely because the element of differences between humans cannot be eliminated.

However, the government must strive to always find a way to overcome or at least reduce the dangers are caused by the conflict, including through education, education is expected to be a vehicle for raising awareness among the community, including the younger generation, to neutralize the impact of diversity in national life. Indonesia.

The concept of pluralism in Indonesia originates from the concept of Fumivall, which describes the condition of the Indonesian nation in the Dutch era. At that time the concept of pluralism is understood as groups of people who stand alone with no bond of unity politics. A minority group of dutchman, a group of The Chinese who are between the majority Dutch and indigenous people. Nasikun then developed the Fumivall concept and divided the plurality of Indonesian society into vertical and horizontal plurality. Vertical plurality is the differences in levels of education, wealth, and social position.

Horizontal plurality includes ethnic, religious and regional differences. Conflicts that happen obviously disturb life together. Atmosphere of anxiety, fear, uncomfortable, suspicion, hostility haunt people's lives. The government must be aware of this situation and bemsaha hard to always look for a way out handle, minimally reducing the negative impact of the arising conflict. If people are aware of this situation and want to re- enact the history of the nation, namely the Youth Pledge event on October 28, 1928, then the spirit of the youth at that time could be an anticipatory step for the younger generation today to ward off conflict vulnerabilities as a result of the existing background in Indonesia.

\subsection{Generating a Sense of Nationalism by Respecting Diversity}

In the Republic of Indonesia we do not recognize that there are ethnic differences, who he is and from which family he belongs which is clear, which is Indonesia, which through the 1928 Youth Congress in Jakarta was bound in the spirit of the Youth Pledge. Ber Homeland One, Homeland Indonesia. Nation One, the Indonesian nation. And Speak the One, Languages Indonesia.

Depart from it all, let us always adhered to the spirit of the air - Unity which is the motto of unifying the nation long ago. Eliminate the thoughts of new defective and is not responsible for the efforts to make a shift in the meaning of a sense of togetherness in the Framework for State Republic of Indonesia (NKRI). All should be aware when rights someone who was born and originated - the proposal from the territory of the country that stretches from Sabang to Merauke also has rights and duties and responsibilities the same for the nation and country. Therefore, we need to appreciate our diversity, certainly, wherever happen to democracy parties either in the center or in the region, should be the arena of the aspirations of the most democratic without overshadowed or haunted and poisoned with the thoughts is narrower than the majority or a group of specific people who want to tarnish the spirit of nationalism in context nation and state.

By holding the spirit of nationalism or appreciate a diversity as contemplated above, then later on society as the holder of sovereignty really will enjoy democratic parties is in direct, general, free and confidential and frank $d$ an unfair accordance with the mandated in Law 1945 and Pancasila. 


\subsection{Influence of Globalization Against Nationalism Values in circles Generation Young}

Globalization quickly penetrated into society, especially in young people. The influence of globalization on youth is very strong. The influence of globalization has made a lot of younger children lose the personality of themselves as a nation of Indonesia. It is indicated by symptoms that arise in daily life - the young people today.

Technology information/Internet is a technology provides information indefinitely and can be accessed by anyone. For young people the Internet has become their meal days. If used properly, of course we get useful benefits. But if do not, we will lose. And now this, a lot of student who used not properly. Not only the internet, there is another mandatory handle for them, namely cellphones. There is no social sense towards the community because they prefer to be busy using cellphones.

Judging from the attitude, many young people whose behavior are not polite and tend to be indifferent and do not care about the environment. Because of globalization embrace freedom and openness so that they act as the heart of them. For example, there are young motorcycle gangs who commit acts of violence that disturb the serenity and comfort of the community. If the influences on the top left, then moral generation of the nation can be broken and there will be anarchist action between groups of young. The relationship with the value of nationalism will decrease because there is no love for the nation's own culture and a sense of caring for the community.

\subsection{Effects of Globalization on Values Nationalism}

The presence of globalization certainly has an impact on the life of country, including Indonesia. This influence includes two sides, positive and negative influences. Impact of globalization is also pervasive in many areas of life, including political, economic, ideological, social, cultural and others. This will certainly affect the use values of nationalism to the nation. Globalization takes place in all areas of life such as the field of ideology, political, economic, social, cultural, defense and security and others. Information and communication technology are a major supporting factor in globalization. Today, the development of technology is so fast all information with various forms and interests can be spread widely throughout the world. Therefore, we cannot avoid globalization.

\subsection{Positive Effect}

Viewed from political globalization, government is run openly and democratically. Because government is part of a country, if the government is run honestly, cleanly and dynamically, certainly, it will get positive response from the people. The positive response in the form of a sense of nationalism towards the country has increased. From the aspect of economic globalization, opening up international markets, increasing employment opportunities and increasing foreign exchange. The more open international markets are, the greater opportunities for cooperation in the national economic sector. With this, it will further improve the economic life of the nation in order to support the national life of the nation and the State.

The influence of globalization in the sector of social culture, we can present any pattern of thinking that good. As build work ethic are high and discipline, as well as mimic Science and Technology (Science and Technology) of other nations have been developed to improve the progress of the nation. In the end, it will bring the progress of the nation and strengthen our sense of nationalism towards the nation. 


\subsection{Negative Influence}

Apart from having a positive impact, the emergence of globalization has also had negative impacts which are no less important to pay attention to. Globalization is able to convince the people of Indonesia that the liberalism can bring progress and prosperity. So it does not rule out a change in direction from the Pancasila ideology to the ideology of liberalism. If things happen consequently a sense of nationalism will disappear.

The emergence of globalization also has an impact on economic aspects. The loss of a sense of love to the product in the country. Therefore, the already growing number of overseas products such as McDonald, Coca - Cola, Pizza Hut, and so on, which flooded the world market in Indonesia. With the loss of a sense of love to the product in the country showing signs of reduced sense of nationalism we are against the nation of Indonesia. In our society, especially young people, many forget about their identity as the Indonesian nation. Because of his lifestyle tend to present any culture of the west are by people the world regarded as the mecca. In addition, globalization has also resulted in a sharp social gap between the rich and the poor. This is due to free competition in economic globalization.

The above influences do not directly impact nationalism. However, on the whole can lead to a sense of nationalism to the nation to be reduced or even disappear. This is because globalization is able to open the horizons of society globally. Whatever is outside the country is considered good and able to give aspirations to our people to be implemented in our country. Based on the analysis and description above, the negative effects of globalization outweigh the positive effects. Therefore, steps are needed to anticipate the negative effects of globalization on the value of nationalism.

\subsection{Indonesian Nationalism Can Be Faded}

Is Indonesian nationalism was going to end soon? Question is relevant to discuss when we will celebrate the Oath of Youth, October 28, 1928, when the youth Indonesia committed to national one, landless water one and speaking one, Indonesia.

\subsection{It Is Not Enough Just Desire to Be United}

Indonesian nationalism, which is an affirmation of self-identity versus colonialismimperialism. Consciousness as a nation that is the result of construction or formation contains serious internal weaknesses when colonialism and imperialism are no longer a threat. Therefore, our nationalism will also disappear if we stop constructing or shaping it without having to call it a new nationalism.

First, several collective experiences should become a "new spirit" generating the spirit of Indonesian nationalism. Second, the Indonesian state is very plural. Identification of an ethnic or religious group in a collective identity as a nation is only possible if the state recognizes, accepts, respects and guarantees their right to life.

People will feel more secure and accepted in their ethnic or religious groups when the state fails to guarantee freedom of religion including freedom of worship and building houses of worship, equality before the law, the right to get cheap and quality education, the right to work and a decent living, and so on. Education in a Pluralistic Society

The function of education for the community is to preserve culture and transfer it to the next generation. Educational institutions, especially schools reflect the value - the value of the dominant of a society. Schools are also the main agents of socialization. After the family, school is a vehicle for continuing the socialization process. After the family, the school becomes a place to instill values, norms, and expectations of the public in person. At school, a person 
acquires a habits, appreciation, and views on life. In school, students learn self-control. Shortly, school is a place where people learn the that will underlie behavior as citizens.

School functions such is the growing ability of member votes were meticulously, increasing awareness of the system value, foster friendships among students who differ temperament, as well as develop an attitude of mutual understanding. In schools too, students are taught openness and dialogue. Robert Dreeben (1968) argues in addition to reading writing and arithmetic, school students also learn the rules of independence (independence), achievement (achievement), universalism (Universalism), and the specifications (specificity). At home, children expect their parents help to do something, at school to do something, children work alone with their responsibilities. If at home a child is specifically needed by his parents, at school the child is treated the same. According to Dreebeb, school is a level of transition from family to society.

The institution has a lot of advantages which can be empowered to reduce conflicts related to the negative impact of the society which is very pluralistic this. Here is a thought how these advantages are empowered so education is really reliable as the power to reduce the conflicts, including: Many problems arise from blind solidarity. This attitude arises because intimacy in the group is very strong, besides that the group means a lot for individuals to find a sense of security from all aspects of their life. Because of that individuals always try to defend their group in any way. This phenomenon is a phenomenon that is less independent, follow-up and tend to be less rational. Students as the younger generation should be given more opportunities to find, find, and process things independently. Attitude echoed should be avoided from the education system to the nation 's.

Attitude ethnocentric is the attitude who put the group itself (the group itself is always better than the other groups). This attitude often give birth to attitudes, such as prejudice, suspicion, stereotypes between groups. The younger generation must be educated to understand each other, and be willing to dialogue, and create opportunities and an atmosphere to interact openly with anyone. Interfaith association, ethnic, and status, should build and developed.

Interactions in plural societies are often characterized by particular patterns. Particular attitude is the attitude of those who always pay attention and give priority for people who have a particular relationship or special relationship with him. His association is limited to people who have a special relationship, namely people who are of the same religion, same ethnicity, or come from the same area. With the right education, educational institutions are expected to develop universal attitudes. Everyone is given the same opportunity and treated equally. The participants were student should be accustomed to associate with anyone just outside of the particular group.

Exclusive attitude, the attitude that separates itself from the other or from the other groups. This attitude also tends to make a person distance himself from others or not take part in activities that involve other groups. This attitude is not well associated with social life. The younger generation must be trained to be accustomed to seeing and solving a problem clearly and specifically, and not confusing it.

Problems majority and minority is also an issue that is prone to conflict. The younger generation must be taught to be sportsmanship and respect everything based on achievement. Achievement should be rewarded, and achievement should be objective, not subjective.

\section{CONCLUSION}

The values of universal let cultivated for generations of young people in pluralistic society. To socialize these universal values, the role of educational institutions is needed. Institute of education has the advantage in the form of human self or group in a plural society. The crisis of authority, modeling, role model, and beliefs. Strongly influence the socialization of 
educational institutions power in order to dampen the vulnerability of conflict in society pluralistic. This is inseparable from the rest of society. The role of educational institutions need to be supported in order to run their function with good socializing the children of the nation owners of times before, values - universal values that exceed the values of particular groups within the pluralistic society

\section{REFERENCES}

[1] Elena Yu. Kolesnikova, Anatoly V. Lubsky, Yury G. Volkov, Natalya K. Bineeva and Victoria O. Vagina, Patriotism and Civic Consciousness of the Youth in the South of Russia, International Journal of Civil Engineering and Technology, 9(9), 2018, pp. 1514-1523.

[2] Chyanika Rajkhowa, Concepts of Nationalism Demonstrated in the Songs of Jyoti Prasad Agarwala, International Journal of Management, 11(11), 2020, pp 1601-1604.

[3] Mica Siar Meiriza, Ery Tri Djatmika, Wahjoedi and Hari Wahyono, the Need for Pluralism in Macroeconomics in State University of Medan, International Journal of Mechanical Engineering and Technology, 10(2), 2019, pp. 476-488

[4] Sri Walny Rahayu, Alternative Dispute Resolution Through Customary Tribunal in the Context of Legal Pluralism in Aceh. International Journal of Civil Engineering and Technology, 9(1), 2018, pp. 472-483. 